\title{
Media Development Learning Game Al-Qur'an Interactive Multimedia Based
}

\author{
Dadan Zaliluddin ${ }^{1}$, Ade Bastian ${ }^{2}$, Arif Muhamad Ramdani ${ }^{3}$

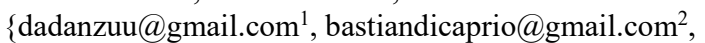 \\ arifmuhamadramdani@gmail.com ${ }^{3}$ \} \\ Informatics, Majalengka University, St. Universitas Majalengka, Majalengka, Indonesia ${ }^{1,2,3}$
}

\begin{abstract}
Madrasah Tsanawiyah (MTs) Al-Ihsan Babakanmanjeti are mostly simple learning methods such as writing on the board, reading through books, and lecture methods, especially in the method of learning to read Al-Qur'an like tajwid. The use of learning media that the authors make, namely Al-Qur'an learning games can be an alternative means for students to increase their interest in learning. The presence of Interactive multimedia-based Al-Qur'an reading media is expected to be able to attract the interest of students and the public to learn to focus more on the material being studied especially reading the Qur'an. The system development method used in making Al-Qur'an learning game applications is to use the MDLC method (Multimedia Development Life Cycle). Questionnaires were given to teachers and students who had tried using the AlQur'an learning game, the questionnaire was made aimed at knowing the responses of teachers and students to the learning game. Based on the survey results, teachers and students gave a positive response to the Al-Qur'an Media Learning Game application with an average percentage of $88.9 \%$ and by teachers an average percentage of $86.8 \%$.
\end{abstract}

Keywords: Tajweed, Learning Game, Multimedia, MDLC

\section{Introduction}

Media is everything that can be used to channel messages from the sender to the recipient so that it can stimulate the mind, feelings, attention and interests and attention of students in such a way that the learning process occurs. By using learning media in the teaching and learning process can generate new desires and interests, arouse motivation and stimulation of learning activities, and even bring psychological influences to students [1].

Al-Ihsan Babakanmanjeti Madrasah Tsanawiyah (MTs) with a total number of 389 students, mostly still simple, such as writing on the board, reading through books, and lecture methods. The use of learning media should be a part that must get the attention of the teacher or facilitator in each learning activity. Therefore the teacher or facilitator needs to learn how to set learning media in order to be effective in achieving learning objectives in the teaching and learning process, one of which is in reading the Qur'an.

As we all know, reading the Qur'an correctly is the duty of every Muslim and Muslim, but the ability of the majority of Muslims is still a concern, this is still evident from the low level of community interaction with the Qur'an, especially among students, there are many factors that cause this situation, including less practical teaching methods, inadequate or personal teachers 
who are less aware of their weaknesses in the Qur'an recitation so they are not interested in learning to read them.

With the discovery of interactive learning media it will feel easier than the methods that are often used by teachers in general. Learning media especially reading the Qur'an for the level or level of education at this time is still in the form of direct delivery from the teacher. Another way that is used for Al-Qur'an reading learning is reading books and lecture methods. But the method is less interactive because books cannot interact directly with students and the lecture method tends to make students passive.

As a support, there must be a media that is able to attract students to study the Qur'an, especially reading the Qur'an. Reading books is an option after getting the material directly from the teaching teacher. Some students will feel bored in learning the material by reading books, so the presence of multimedia-based learning media of Al-Qur'an reading Interactive is expected to be able to attract students and the general public to learn to focus more on the material learned especially reading the Qur'an.

\section{Literature Research}

\subsection{Multimedia}

Multimedia comes from multi words and media. Multi comes from Latin, which is a nouns which means many or various. While the word media comes from Latin, which is a medium that means an intermediary or something that is used to deliver, convey, or bring something [2].

American Heritage Electronic Dictionary (1991) Medium can be interpreted as a tool for distributing and presenting information. Based on that multimedia is a combination of various media (file format) in the form of text, images (vector or bitmap), graphics, sound, animation, videos, interactions, etc. that have been packaged into digital files (computerized), used to convey or deliver messages to the public [2].

\subsection{Adobe Flash Professional CS6}

According to Island Script (2008) flash is one of the animated software released by Macromedia which has now been adopted by Adobe, Inc. Adobe Flash Professional CS6 is an Adobe Flash version that has been updated from previous versions, namely Adobe Flash CS3 Professional, Adobe Flash CS4 Professional, and Adobe Flash Professional CS5. Adobe Flash Professional CS6 is an animated graphics software that can create graphic objects and animate them so that we can directly create design objects without having to use supporting graphics software such as Illustrator or Photoshop. Adobe Flash Professional CS6 is equipped with several features that are not owned by the previous version of Adobe Flash, such as a bone tool that functions to create recurring animations by adding joint points to objects, a 3D Rotation tool that serves to make $3 \mathrm{D}$ rotations on objects based on the $\mathrm{X}, \mathrm{Y}$, and $\mathrm{Z}$, as well as changes in panel layout that make it easier for users to operate.

According to Ariesto Hadi Sutopo (2003) Adobe Flash Professional CS6 is software that is able to produce presentations, games, films, interactive CDs, and learning CDs, as well as to create interactive, interesting and dynamic web sites. Adobe Flash Professional CS6 is able to complete websites with various kinds of animations, sounds, interactive animations, etc. so that users while listening to their explanations can see animated images, as well as read explanations 
in text form. Adobe Flash Professional CS6 as a software for making interactive learning media based on several advantages it has.

\subsection{Learning Media}

Learning media is the media used in learning, which includes the teacher's teaching aids as well as the means of messenger from learning resources to the recipient of student learning messages. As a presenter and distributor of messages, learning media in certain cases can represent teachers presenting learning information to students. If the media program is designed and developed properly, then the function will be played by the media even without the existence of the teacher. In general, the benefits of learning media are to facilitate interaction between teachers and students so that learning activities are more affective and efficient [4].

\subsection{Reading of the Qur'an}

Reading or reading in Indonesian comes from the basic word "read" which can simply be interpreted as saying the spoken language lafadz according to certain rules. Basically reading covers several aspects, namely:

1) Visual activity which involves the eye as the senses.

2) Activities that are organized and systematic, which are arranged from the beginning to the end.

3) Something abstract (theoretical), but meaningful.

4) Something related to certain languages and communities [5].

As mentioned above in the reading process there are two main aspects which are interrelated, namely the reader and reading material. In terms of the actors, reading is one of the abilities (mastery) of one's language. Other abilities in language, namely, the ability to listen (listen), speak, and write. The ability to listen and speak is grouped into oral communication while the ability to read and write is included in written communication [5].

\subsection{MDLC (Multimedia Development Life Cycle)}

In scientific study Siti Nurajizah (2016) there are stages in MDLC that are systematically arranged [3], namely:

1) Concept (Concept)

The concept stage is the initial stage in the MDLC cycle. In the concept stage, it starts by determining the purpose of making the application and determining the application user. In this stage, identification of the estimated needs resulting from observations in the study is also carried out and determine the basic rules for design, such as the size of learning media, etc.

2) Design Design (Design)

A mature concept makes it easy to describe what should be done. The purpose of the design stage is to make specifications in detail about the project architecture, the appearance and requirements of the project material, and style. This stage uses a storyboard to describe a series of stories or descriptions of each scene so that it can be understood by the user, by listing all multimedia objects and links to other scenes.

3) Material Collection (Material Collecting)

Collecting material is the stage for collecting materials that are suitable for your needs. These materials include images, photos, animation, video, audio, and text, both those that 
have been made or that still need to be modified according to existing needs. These materials can be obtained free of charge or by ordering to other parties in accordance with the design made in the previous stage.

4) Assembly

The assembly stage is the stage of making all multimedia materials. Applications that will be created are based on the design stage, such as storyboards. This stage usually uses authoring software, such as Macromedia Director or Adobe Flash.

5) Testing (Testing)

Tests are carried out to ensure that the results of making multimedia applications are in accordance with the plan. There are two types of testing used, namely alpha testing and beta testing. Alpha testing such as displaying each page, function keys and the sound produced. If there is a malfunction, the application will be fixed immediately. If you have passed the alpha test, it will be followed by beta testing. Beta testing is a test performed by a user.

6) Distribution (Distribution)

This stage is the last stage in the multimedia development cycle. Distribution can be done after the application is declared feasible to use. At this stage, the application will be stored on a storage media such as a $\mathrm{CD}$, mobile device or website. If the storage media is not enough to hold the application, compression on the application will be done. The evaluation phase is included in this stage. The evaluation is needed for the development of products that have been made in advance to make it better.

\subsection{System Planning}

The design of the system has two purposes that meet the needs of the user (user) and to provide a clear picture and complete design to the programmer (developer) and other techniques involved in making the system.

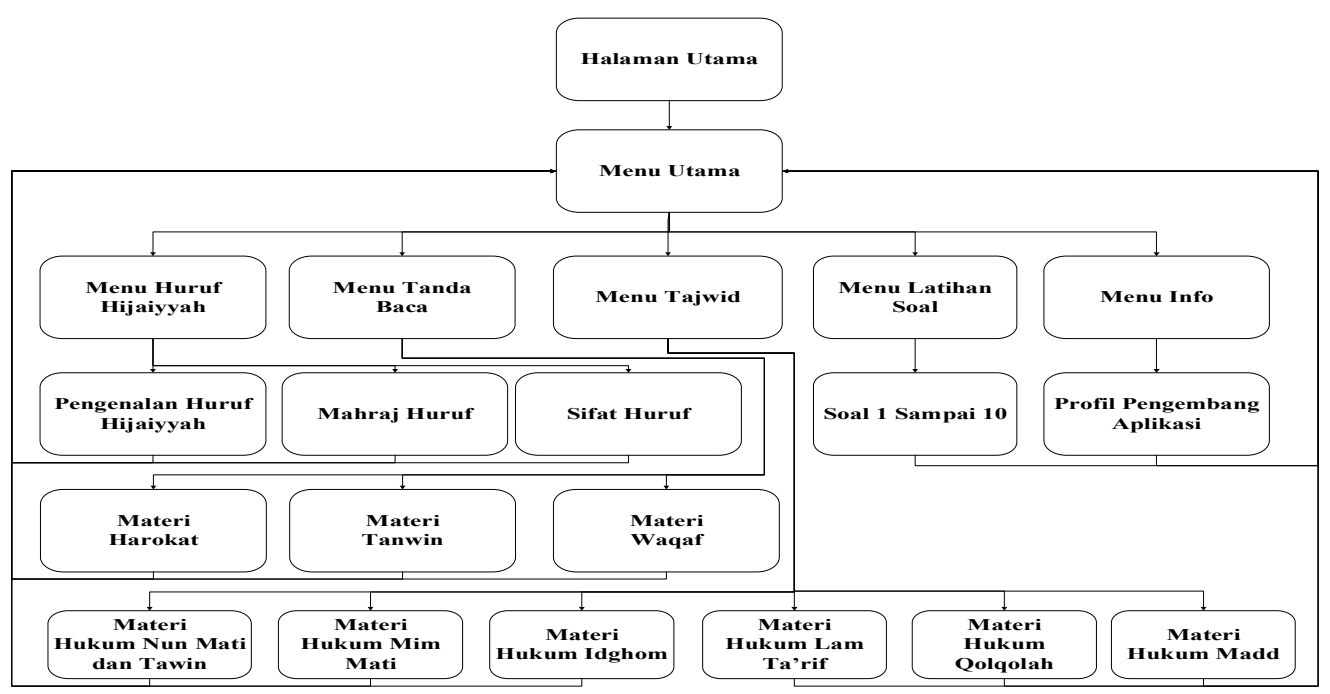

Figure 1. Flow Chart of the Al-Qur'an Learning Game Application Menu 


\section{Results And Discussion}

\subsection{Planning Storyboard}

In the planning of this Storyboard is made to illustrate to users in the changing gameplay application so that the user can clearly understand the flow contained in the learning game app clearly. Below is a Storyboard created:

1) Storyboard Menu Intro

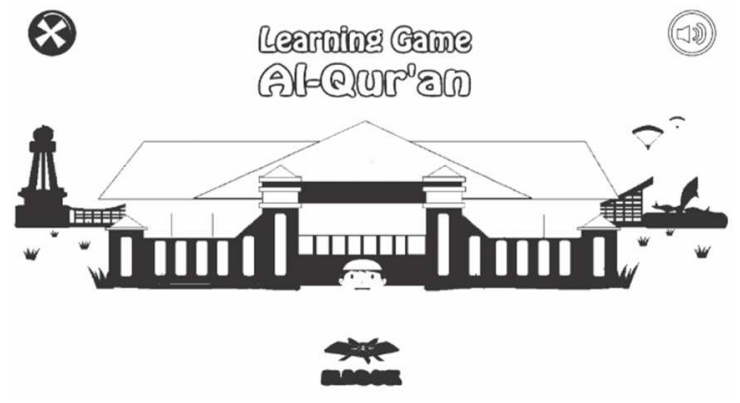

Figure 2. Planning Storyboard Intro Menu

2) Storyboard Main Menu

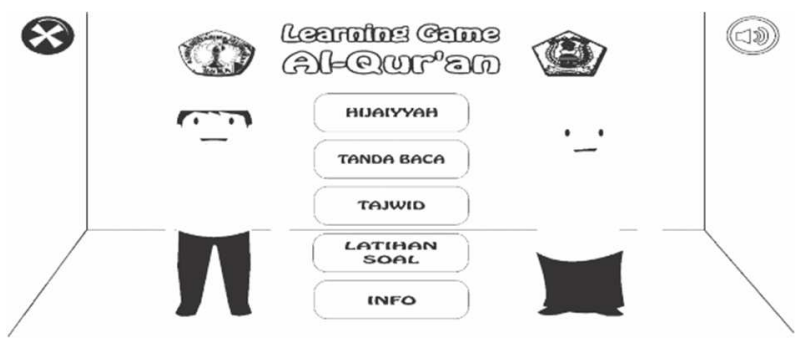

Figure 3. Storyboard Planning Main Menu

3) Storyboard of Hijaiyyah Material

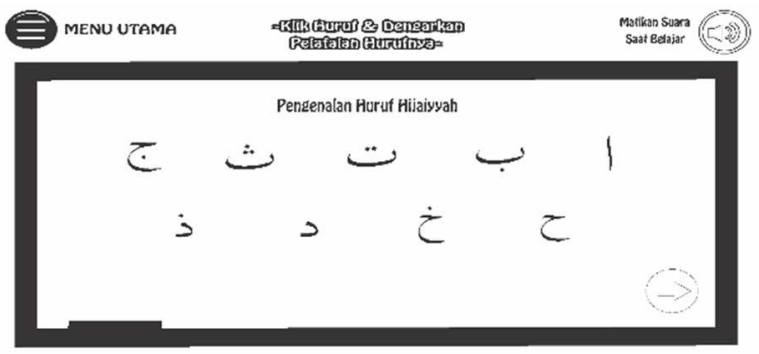

Figure 4. Storyboarding Planing of Hijaiyyah Material 


\subsection{Interface Display Design}

Here are some of the interfaces that have been designed, namely in the form of screenshots of the Al-Qur'an learning game application according to the storyboard design:

1) Display of Application Intro Interface.

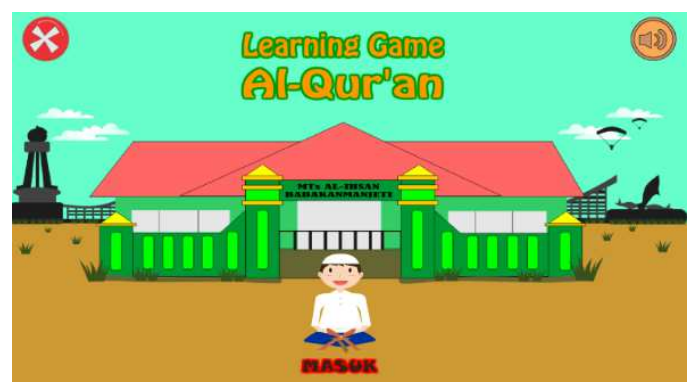

Figure 5. Display Interface of Application Intro

4) Display of the Main Menu Application Interface

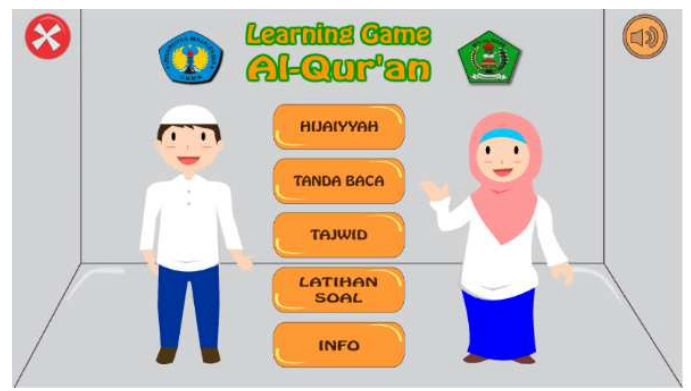

Figure 6. Interface Display of the Main Menu Application

5) Display of Interface Material of Hijaiyyah

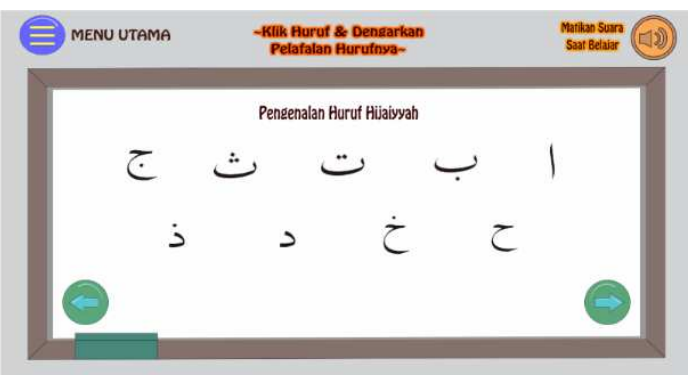

Figure 7. Display of Interface Material of Hijaiyyah 


\section{Conclusion}

Based on the results of testing and implementation that have been carried out in the previous chapters, the conclusions of the Final Project are titled "Development of Al-Qur'an Learning Media Based on Interactive Multimedia", so some conclusions can be drawn as follows:

1. The teachers in carrying out learning activities to read the Qur'an to the students at MTs Al-Ihsan Bababanmanjeti are still manual and simple. Interactive media such as the AlQur'an Learning Game can be an alternative so that teachers can attract more interest in learning to read the Qur'an to students at MTs Babakanmanjeti.

2. This Al-Qur'an Media Learning Game was developed with Adobe Flash Professional CS6 and Corel Draw X8 software using the Multimedia Development Life Cycle (MDLC) method as an effective and interesting learning media for the Qur'an for students at Al MTs -Ihsan Babakanmanjeti.

3. Based on the results of the survey with Questionnaire, most of the students who took the survey gave a positive response to the Al-Qur'an Media Learning Game with an average percentage of $88.9 \%$ and by the teacher the average percentage was $86.8 \%$.

\section{References}

[1] Pratama Ardhiansyah Dhimas, Rakhmawati Lusia, Pengembangan Media Pembelajaran E-Book Interaktif Pada Mata Kuliah Elektronika Digital Di Jurusan Teknik Elektro Unesa. Jurnal Pendidikan Teknik Elektro Vol.2 No.1, Surabaya. (2013)

[2] Munir. Multimedia Konsep dan Aplikasi Dalam Pendidikan. Alfabeta, Bandung.(2011)

[3] Nurajizah Siti, Implementasi Multimedia Development Life Cycle Pada Aplikasi Pengenalan Lagu Anak-Anak Berbasis Multimedia, Jurnal PROSISKO Vol.3 No.2, Jakarta. (2016)

[4] Siyamto, Fairuzabadi Muhammad, Media Pembelajaran Terjemah Al-Qur'an Perkata Juz 1 Dan Juz 2 Menggunakan Adobe Flash. Seminar Nasional Universitas PGRI, Yogyakarta. (2015)

[5] Srijatun,. Implementasi Pembelajaran Baca Tulis Al-Qur'an Dengan Metode Iqro Pada Anak Usia Dini di RA Perwanida Slawi Kabupaten Tegal. Jurnal Pendidikan Islam Vol.11 No.1, Semarang. (2017) 